Bull. Geol. Soc. Finland 41, 99-105 (1969)

\title{
TRIPLITE AND WOLFRAMITE FROM A GREISEN-BORDERED VEINLET IN EURAJOKI, SW FINLAND
}

\author{
Ilmari Haapala and Pent'ti Ojanperä \\ Geological Survey of Finland, Otaniemi
}

\begin{abstract}
Triplite and wolframite are described from a greisen-bordered veinlet associated with the local varieties of the Laitila rapakivi granite massif. The chemical analysis, unit cell dimensions and specific gravity are given for these minerals, and in addition the optical properties and the indexed powder diffraction data for triplite. Single-crystal studies of triplite gave a space group $I 2, I 2 / \mathrm{m}$ or $I m$, and a pseudo space group $I 2 / \mathrm{c}$ or $I c$. A comparison is made with other mineral occurrences of the same type. The hybnerite-ferberite ratio $(0.29)$ of the wolframite is within the range generally observed for wolframites occurring in greisen veins and quartz veins.
\end{abstract}

\section{Introduction}

During the exploration work carried out by the Geological Survey in the summer of 1967 in the Eurajoki area, SW Finland, several sets of greisen-bordered veins and some irregular greisen bodies were found. The geology of the area is described briefly by Kahma (1951). The veins and greisen bodies are situated in the local varieties of the Laitila rapakivi granite complex. Most of the veins are in the so called »Tarkki granite» (an orthoclase-biotite-hornblende granite) and some in the »Väkkärä granite» (a porphyritic microcline-biotite granite with some topaz). The mineralogy of the greisens and associated fracture fillings is very variable. In addition to quartz and mica minerals (in part Li-bearing), they contain commonly chlorite, beryl, almandine, fluorite, topaz and apatite as gangue minerals. The most common ore minerals are sphalerite, chalcopyrite, cassiterite, wolf- ramite, molybdenite, scheelite, gahnite, ilmenite, rutile, arsenopyrite, pyrite, galena and stannite. In connection with the diamond drillings carried out at a vein set between the villages of Lapijoki and Hank kila, also triplite was found in association with wolframite, in one greisen-bordered veinlet (drill hole No. 8, depth $21.4 \mathrm{~m}$ ). The purpose of this paper is to give a mineralogical description of this rare type of mineral occurrence. The chemical analyses of triplite and wolframite were made by Pentti Ojanperä, the other mineralogical studies and the writing of the manuscript by Ilmari Haapala.

\section{Petrography}

In the greisen-bordered veinlet under consideration there is a definite zonal structure 


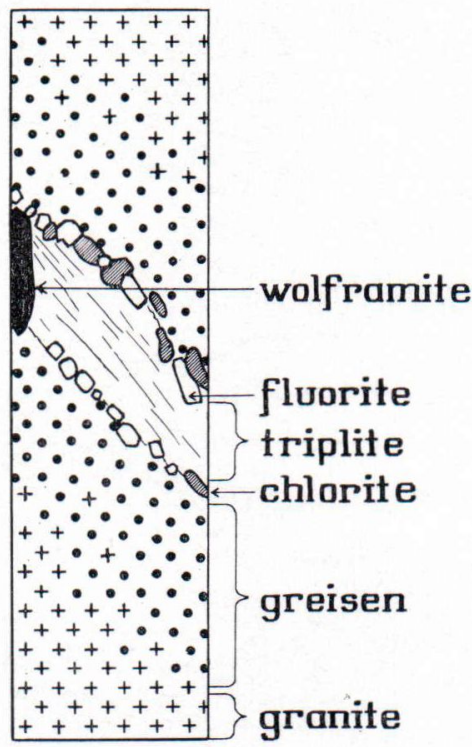

Fig. 1. The greisen-bordered veinlet with triplite and wolframite. Eurajoki, $\mathrm{BH} 8$, depth $21.4 \mathrm{~m} .2 / 3 \times$ nat. size.

(Fig. 1). The central part is occupied by a massive triplite veinlet, about $1 \mathrm{~cm}$ in width. Usually in the Eurajoki area the central veins of the greisens consist essentially of quartz with or without beryl, but in this ase these minerals are lacking. A flattened wolframite crystal, about $2 \mathrm{~cm} \times 2 \mathrm{~cm} \times 1 / 2 \mathrm{~cm}$ in size, is situated in the triplite veinlet. There are fluorite and chlorite crystals, about $1-3 \mathrm{~mm}$ in diameter, as well as some small spessartine crystals on the borders of the triplite veinlet. On both sides on the triplite veinlet there is normal greisen, which grades into unaltered granite. The total width of the greisen and the central veinlet is only about $5-6 \mathrm{~cm}$. The chief minerals of the greisen proper are quartz, mica minerals, chlorite, fluorite and spessartine. The mica consists in part of green, brown or pale brown mica with high birefringence, in part of sericite. Chalcopyrite, wolframite and sphalerite occur in small amounts. The border between the greisen and the granite is gradual. The most easily altered mineral in the Tarkki granite is plagioclase, which has partly altered into sericite, although all the other minerals are unaltered.

\section{Triplite}

The central veinlet of the greisen consists of almost pure triplite. Along the cracks triplite has altered to a slight degree into an extremely fine-grained opaque pigment, obviously consisting of iron and manganese oxides. Along the vein margins triplite is replaced by apatite, which has $\omega=1.636 \pm 0.002$ and $\varepsilon=1.633 \pm 0.002$. The apatite was also identified with an X-ray powder photograph. Apatite replacing triplite has been described by Pehrman (1943), Volborth (1954) and Fisher (1957).

The colour of triplite is brown with a greasy lustre. The mineral has three cleavage directions, which were identified by single-crystal X-ray studies from a cleavage fragment as $\{001\}$ (good), $\{010\}$ (moderate) and $\{100\}$ (poor). The optical orientation was measured from the same cleavage fragment with a universal stage. A thin section, made from crushed triplite grains, was also used in the optical study.

A crystal splinter of triplite was used for the determination of the space group and the unit cell dimensions. From this splinter an $a$-axis zero-level Weissenberg photograph was taken with Ni-filtered $\mathrm{Cu}$ radiation, as well as $b$ - and $c$-axis zero-, first- and second-level precession photographs using Zr-filtered Mo radiation. The choice of the axes was the same as that of Richmond (1940) and Wolfe and Heinrich (1947). Among the general reflections (bkl) only those with $b+k+l$ even appeared. No other conditions for the non-extinction of the reflections were noticed. These data are compatible with space groups $I 2, I 2 / m$, and $I m$, in accordance with the studies of Wolfe and Heinrich, (op. cit.) who gave the space group $I 2 / m$ for triplite. If a base-centered instead of body-centered cell is chosen, the space group is $C 2, C 2 / m$, or $C m$. The transformation matrix from the $I$ 


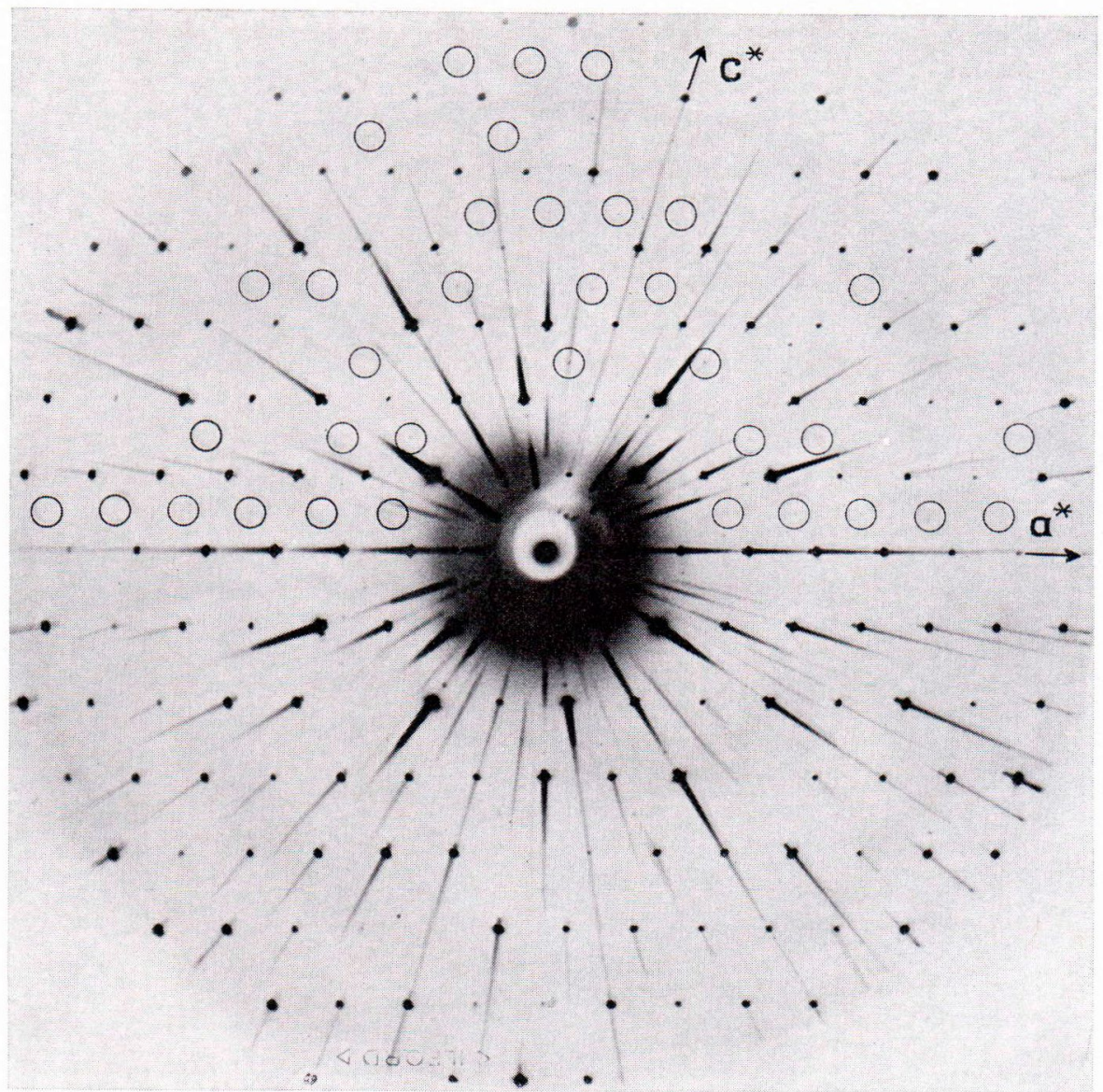

Fig. 2. $b$-axis zero-level precession photograph of triplite from Eurajoki. $\mathrm{Zr}$-filtered Mo radiation, $\mu=30^{\circ}$. Natural size, $F=6.0 \mathrm{~cm}$. The weak reflections with $h$ and $l$ odd are marked with circles on the upper side of the film.

cell to the $C$ cell is $\overline{1} 0 \overline{1} / 010 / 001$. Thus the $\{001\}$ cleavage of the $I$ cell changes to $\{\overline{1} 01\}$ in the $C$ cell.

The reflections of the $b 0 l$ type gave a well pronounced pseudo space group $I 2 / c$ or $I c$ because the reflections with $h$ and $l$ odd were extremely weak. In fact they were noticed only in over-exposed films (Fig. 2). The pseudo space group corresponds to the space group $I$ 2/c given by Waldrop (1968) for triplite on the basis of crystal structure analysis. Both the studies of Wolfe and Heinrich (op. cit.) and Waldrop (op. cit.) referred to the triplite from the Mica Lode pegmatite, Fremont County, Colorado (see Appendix).
The unit cell dimensions (Table 2) were calculated from the zero-level precession photographs. These films were calibrated with the reflections of an oriented silicon crystal, exposed on the same films with the same instrument settings. For the base-centered cell the cell dimensions should be $a_{\mathrm{o}}=13.348 \AA, b_{\mathrm{o}}=6.505 \AA$, $c_{0}=10.069 \AA$ and $\beta=119^{\circ} 47^{\prime}$. No reflections indicating the doubling of $b_{0}$ could be detected, as is the case with mineral wagnerite in the triplite group (see Strunz, 1966). The indexing of the powder pattern and the calculation of the interplanar spacings, given in Table 1, was based on the crystallographic data obtained from the single-crystal studies. The powder pattern was 


\section{TABLE 1}

$\mathrm{X}$-ray powder diffraction data for the triplite from Eurajoki. Mn-filtered $\mathrm{Fe}$ radiation, silicon as an internal standard. The $2 \Theta$ values smaller than $60^{\circ}$ are given for $\mathrm{K} \alpha$ radiation $(\lambda=1.93728 \AA)$, those greater than $60^{\circ}$ for $K \alpha_{1}$ radiation $(\lambda=1.93597 \AA)$

\begin{tabular}{|c|c|c|c|c|}
\hline$b k l$ & I & $2 \Theta$ meas. & ${ }^{d}$ meas. & $d_{\text {calc. }}$ \\
\hline$\overline{2} 02$ & & & & 4.369 \\
\hline$\overline{2} 11$ & 10 & 26.02 & 4.303 & 4.304 \\
\hline 211 & 25 & 30.66 & 3.664 & 3.667 \\
\hline 112 & 20 & 32.72 & 3.439 & 3.446 \\
\hline 202 & 50 & 34.50 & 3.267 & 3.277 \\
\hline 020 & & & & 3.253 \\
\hline$\overline{1} 21$ & 60 & 37.10 & 3.045 & 3.048 \\
\hline 121 & & & & 2.914 \\
\hline 400 & & & & 2.896 \\
\hline$\overline{4} 02$ & 100 & 39.45 & 2.870 & 2.870 \\
\hline 220 & 15 & 40.00 & 2.832 & 2.836 \\
\hline$\overline{4} 11$ & 20 & 41.46 & 2.737 & 2.740 \\
\hline 022 & 10 & 42.20 & 2.691 & 2.697 \\
\hline$\overline{2} 22$ & 20 & 43.62 & 2.607 & 2.609 \\
\hline$\overline{3} 21$ & 20 & 45.17 & 2.522 & 2.523 \\
\hline$\overline{2} 04$ & 5 & 45.71 & 2.494 & 2.494 \\
\hline 411 & 5 & 47.75 & 2.392 & 2.398 \\
\hline$\overline{4} 13$ & & & & 2.368 \\
\hline 213 & & & & 2.353 \\
\hline$\overline{114}$ & 10 & 48.87 & 2.342 & 2.341 \\
\hline 321) & 10 & 49.75 & 2.303 & 2.309 \\
\hline 222$\}$ & & & & 2.309 \\
\hline$\overline{5} 12$ & 15 & 51.63 & 2.224 & 2.225 \\
\hline 420 & 10 & 53.33 & 2.158 & 2.163 \\
\hline$\overline{4} 22$ & 10 & 53.54 & 2.151 & 2.152 \\
\hline$\overline{2} 31$ & 10 & 57.08 & 2.027 & 2.028 \\
\hline$\overline{5} 211$ & 15 & 60.15 & 1.932 & 1.938 \\
\hline $024 j$ & 13 & 00.15 & 1.932 & 1.938 \\
\hline$\overline{5} 23$ & 20 & 64.25 & 1.820 & 1.822 \\
\hline$\overline{4} 15$ & 10 & 65.28 & 1.795 & 1.798 \\
\hline 521 & 10 & 66.19 & 1.773 & 1.776 \\
\hline 314 & 15 & 66.76 & 1.759 & 1.758 \\
\hline 325 & 10 & 70.47 & 1.678 & 1.682 \\
\hline$\overline{4} 33$ & 15 & 72.14 & 1.644 & 1.650 \\
\hline 233 & 25 & 72.49 & 1.637 & 1.645 \\
\hline
\end{tabular}

recorded with a Philips wide-range goniometer by using $\mathrm{Mn}$-filtered $\mathrm{Fe}$ radiation, a scanning speed of $1^{\circ}$ per 4 minutes and silicon as an internal standard. The intensities of the reflections were measured from the heights of the peaks on the chart.

For the chemical analysis, triplite was crushed and hand-picked under a binocular microscope.
It was not possible to completely separate the oxide pigment from the triplite. For this reason the contents of the iron and manganese oxides in the analysis (Table 2) are probably slightly too high for pure triplite. The chemical formula for the mineral, calculated on the basis of $5(\mathrm{O}, \mathrm{F}, \mathrm{OH})$, is

$$
\begin{gathered}
\left(\mathrm{Mn}_{1.02}, \mathrm{Fe}^{2+}{ }_{0.73}, \mathrm{Ca}_{0.12}, \mathrm{Fe}^{3+}{ }_{0.09},\right. \\
\left.\mathrm{Mg}_{0.07}\right)_{2.03} \mathrm{P}_{0.93} \mathrm{O}_{3.78}\left(\mathrm{~F}_{0.96}, \mathrm{OH}_{0.26}\right)_{1.22},
\end{gathered}
$$

compared with the ideal formula of triplite $(\mathrm{Mn}, \mathrm{Fe})_{2} \mathrm{PO}_{4}(\mathrm{~F}, \mathrm{OH})$. The compositions derived from the measured specific gravity and calculated density (ca. 40 and 48 mole per cent $\mathrm{Fe}_{2} \mathrm{PO}_{4} \mathrm{~F}$ respectively) by using Winchells' (1958) diagram are in fairly good agreement with the chemical analysis $(100 \cdot \mathrm{Fe} /(\mathrm{Mn}+\mathrm{Fe})=$ 44.5). Using Heinrich's (1951) triangular diagrams relating $\mathrm{MnO}, \mathrm{FeO}+$ equivalent $\mathrm{Fe}_{2} \mathrm{O}_{3}$ and $\mathrm{MgO}+\mathrm{CaO}$ to the refractive indices $\alpha$ and $\gamma$, the estimated $\alpha 1.674$ and $\gamma 1.691$ closely agree with the measured values. The calculated density was obtained from the analysis and cell dimensions by assuming $40(\mathrm{O}, \mathrm{F}, \mathrm{OH})$ per unit cell.

\section{Wolframite}

A flattened wolframite crystal, about $2 \mathrm{~cm} \times$ $2 \mathrm{~cm} \times 1 / 2 \mathrm{~cm}$ in size, was situated in the triplite veinlet. Because the crystal faces were striated and rounded, no exact measurement of the faces was possible. In addition to this large crystal there were some very small wolframite crystals also in the greisen proper.

The large wolframite crystal was used for detailed mineralogical studies. This crystal was especially suitable for chemical analysis, because it had not altered to any observable degree into scheelite, as the wolframites in the Eurajoki greisens usually have. Slight quantities of a yellow earthy alteration product were sometimes observed on the fractures of this wolframite crystal. As cleavage directions were identified 
TABLE 2

Chemical composition and physical properties of the triplite from Eurajoki. Chemical analysis by Pentti Ojanperä

\begin{tabular}{|c|c|c|c|}
\hline $\mathrm{Wt} \%$ & Mol. \% & $\begin{array}{c}\text { Number of ions on the basis of } 40 \\
(\mathrm{O}, \mathrm{OH}, \mathrm{F})\end{array}$ & Physical properties \\
\hline 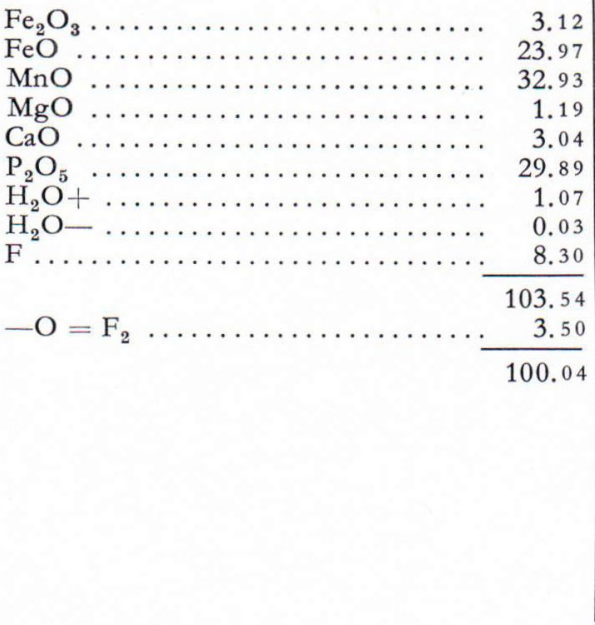 & $\begin{array}{r}1.22 \\
20.75 \\
28.87 \\
1.84 \\
3.37 \\
13.10 \\
3.69 \\
27.17 \\
100.01\end{array}$ & 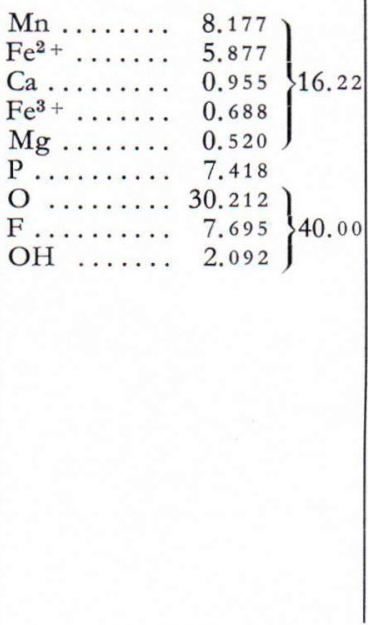 & 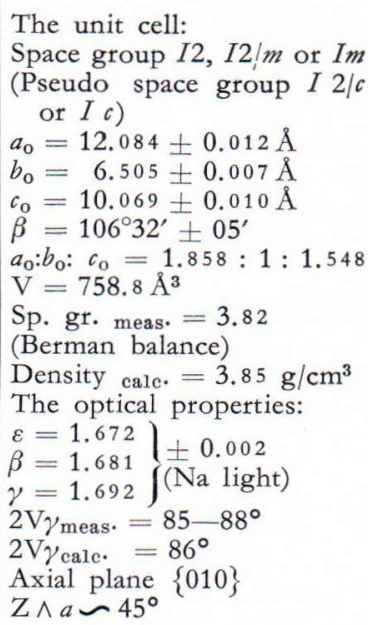 \\
\hline
\end{tabular}

by single-crystal X-ray studies $\{010\}$ and $\{100\}$. One cleavage fragment was used to obtain a $c$-axis rotation photograph with $\mathrm{Ni}$-filtered $\mathrm{Cu}$ radiation as well as $a$ - and $b$-axis zero-, firstand second-level precession photographs with Zr-filtered Mo radiation. The systematic extinctions are in agreement with the space group $P$ $2 / c$ given by Broch (1929) on the basis of crystal structure analysis.

The unit cell dimensions $a_{0}, b_{0}$ and $c_{0}$ (Table 3 ) were calculated by the least-squares method from the X-ray powder pattern reflections 100 , $110,011,020,002$ and 030 . The powder pattern was recorded with a Philips wide-range goniometer by using $\mathrm{Mn}$-filtered Fe radiation, scanning speed $1^{\circ}$ per 4 minutes and silicon as an internal standard. The $2 \Theta$ values used were the averages of five records. The angle $\beta$ was measured from the $b$-axis zero-level precession photograph. Because the powder pattern did not markedly differ form those given in literature (e.g. Sasaki, 1959) for iron-rich wolframites, it is not repeated in this paper.
Before the wet chemical analysis the wolframite was qualitatively tested with an $\mathrm{X}$-ray fluorescence spectrograph by Mr. Väinö Hoffren, Mag. Phil. (quantitative analysis of $\mathrm{Nb}_{2} \mathrm{O}_{5}$ ), and with an optical spectrograph by Mr. Arvo Löfgren, Mag. Phil. (quantitative determination of $\mathrm{Sc}_{2} \mathrm{O}_{3}, \mathrm{In}_{2} \mathrm{O}_{3}, \mathrm{TiO}_{2}$ and $\mathrm{SnO}_{2}$ ). According to the chemical analysis (Table 3), the Eurajoki wolframite contains 75 mole per cent ferberite (total iron as $\mathrm{Fe}^{2+}$ ), 22 mole per cent hybnerite and 2 mole per cent scheelite. The $\mathrm{Sc}_{2} \mathrm{O}_{3}$ content ( 0.23 weight per cent) is somewhat greater than is usual in iron- rich wolframites (see Leutwein, 1951). Yttrium and rare earths were not detected.

The relationships between the unit cell dimensions and the compositions of wolframites have been studied by several authors. Obviously the most accurate are the curves given by Sasaki (1959) for synthetic wolframites. Plotting the cell dimensions as well as the values of $2 \Theta_{110}$ $2 \Theta_{011}$ and $2 \Theta_{111}-2 \Theta_{\overline{111}}\left(2 \Theta_{11 \overline{1}}-2 \Theta_{111}\right.$ in Sasaki, op. cit.) given in Table 3 on the curves, we get the following mole per cents of $\mathrm{MnWO}_{4}$ for the 
TABLE 3

Chemical analysis and physical properties of the wolframite from Eurajoki. Chemical analysis by Pentti Ojanperä

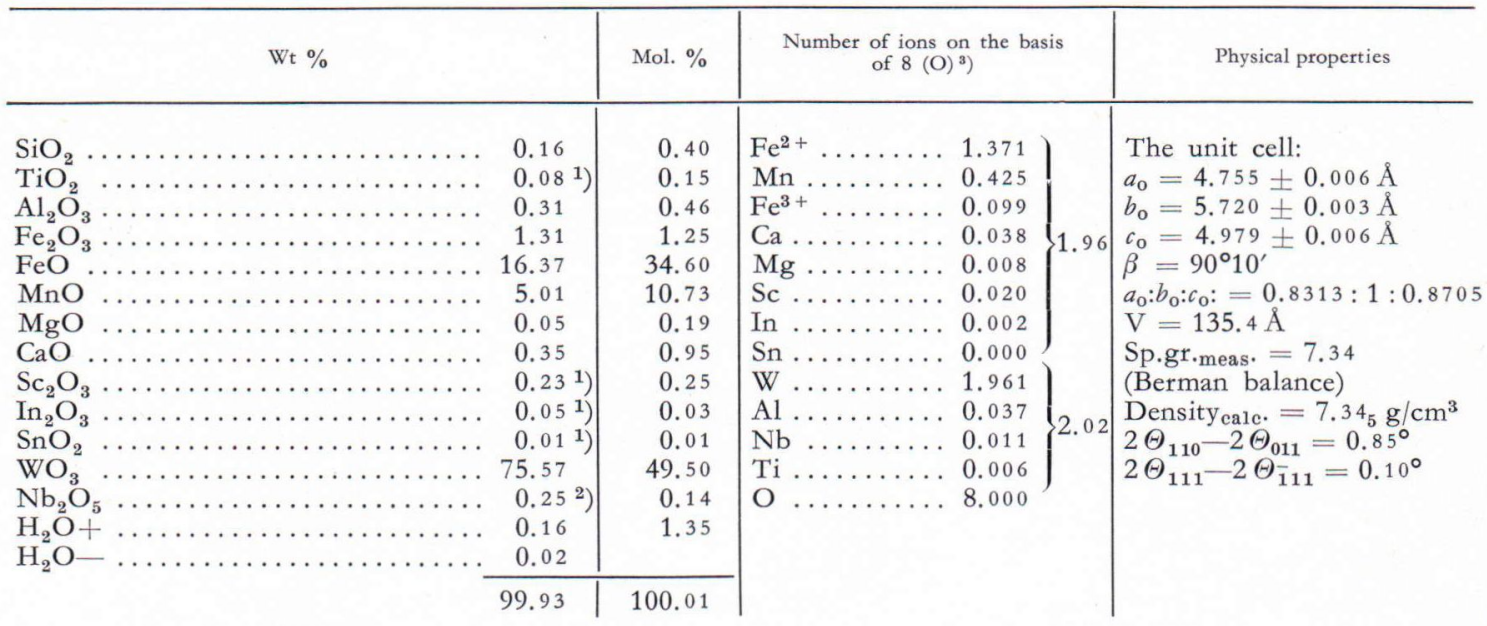

1) Spectrographic determination by Arvo Löfgren

2) X-ray fluorescence analysis by Väinö Hoffren

3) $\mathrm{SiO}_{2}$ and $\mathrm{H}_{2} \mathrm{O}+$ omitted

Eurajoki wolframite: $23\left(a_{0}\right), 26\left(b_{0}\right), 41\left(c_{0}\right)$, $19(\beta), 7\left(2 \Theta_{110}-2 \Theta_{011}\right)$ and $21\left(2 \Theta_{111}-2 \Theta_{\overline{111}}\right)$. The most accurate values are those derived from $a_{0}, b_{0}, \beta$ and $2 \Theta_{111}-2 \Theta_{\overline{1} 11}$, because their variation range is comparatively great. The average of these values (22 mole per cent $\mathrm{MnWO}_{4}$ ) is in very good agreement with the composition obtained from the chemical analysis.

\section{Conclusions}

The greisen-bordered veinlet described is very small and, of course, of no economic importance. A short description of it is given, because it is the only triplite-bearing vein of this type known in Finland. Triplite is typically a pegmatite mineral, usually occurring in pegmatites in late stage assemblages (e.g. Wolfe and Heinrich, 1947; Volborth, 1954). In Finland triplite has been described from the pegmatite areas Tam-
mela-Somero (Mäkinen, 1913), Kemiö (Pehrman, 1945) and Eräjärvi (Volborth, op. cit.), and mentioned from Helsinki (unknown occurrence; Laitakari, 1967). Sometimes triplite is found, however, in greisens or related rocks in association with wolframite and/or cassiterite in a similar way to that in Eurajoki (e.g. Heinrich, 1951; Oelsner, 1952, pp. 49-51; Fisher, 1957). Fluorite, topaz and apatite are, however, by far the most common fluor minerals in greisens.

In Finland wolframite in outcrop has been described in only one locality (Knorring, 1955) and in glacial boulders in three localities (Laitakari, op. cit.). The composition of wolframite varies very strongly depending on the mineral paragenesis and consequently on the crystallization temperature (Oelsner, op. cit.; Schröcke, op.cit.). Thus the ratio hybnerite: ferberite $(\mathrm{H} / \mathrm{F}$ coefficient $)$ is greater than 1 in pegmatites, and smaller than 0.05 in hydrothermal deposits $\left(\mathrm{T} \lesssim 350^{\circ} \mathrm{C}\right.$ ). In greisen veins and quartz veins (not those with pyrrhotite) which have crystal- 
lized between about $400^{\circ}$ and $350^{\circ} \mathrm{C}$ the ratio is between 0.5 and 0.1 . In the wolframite from the greisen-bordered veinlet now described, the ratio is 0.29 (total iron as $\mathrm{Fe}^{2+}$ ) which is in good agreement with the diagrams of the cited authors.

Acknowledgements - The authors are indebted to Mr Arvo Löfgren, Mag. Phil., for the spectrochemical analysis, to Mr. Väinö Hoffrén, Mag. Phil., for the X-ray fluorescence analysis, and to Miss Karin Dahl for drawing the Fig. 1. Sincere thanks are also due to Dr. Atso Vorma for reviewing the manuscript.

\section{APPENDIX}

After the manuscript went to press, one of the writers (I. H.) received a letter from Mrs. Lyneve Waldrop, Massachusetts Institute of Technology, giving further data on the crystallography of the Mica Lode triplite. According to Mrs. Waldrop the triplite studied by her appears to have an approximately random distribution of $\mathrm{Mn}-\mathrm{Fe}, \mathrm{Ca}$ and $\mathrm{Mg}$ between the two metal sites. She states that with the same coordinates for all atoms, the symmetry could be reduced to $I 2$ (Eurajoki triplite) if the metal atoms adopt ordered arrangement among sites which are equivalent in $I 2 / c$.

\section{REFERENCES}

BROCH, E. K. (1929) Untersuchungen über Kristallstrukturen des Wolframmittypus und des Scheelittypus. Vidensk.-Akad. Oslo Skr. Mat.-nat. K1., No. 8.

Fisher, D. J. (1957) Isokite and triplite from Bohemia. Mineral. Mag. 31, pp. 587-602.

Heinrich, E. Wm. (1951) Mineralogy of triplite. Am. Mineral. 36, pp. 256-271.

Kaнma, A. (1951) On contact phenomena of the Satakunta diabase. Bull. Comm. géol. Finlande 152.

von Knorring, O. (1955) A mineralogical and geochemical study of the metamorphic iron ores of S. W. Finland. An unpublished Ph.D. thesis, University of Leeds.

LaItAkari, A. (1967) Index of Finnish minerals with bibliography. Bull. Comm. géol. Finlande 230.

Leutwein, F. (1951) Die Wolframitgruppe. Mineralogisch-lagerstättenkundliche Untersuchungen. Freiberger Forsch. -H. C 3, pp. 8-19.

Mäkinen, E. (1913) Die Granitpegmatite von Tammela und ihre Minerale. Bull. Comm. géol. Finlande 35.

Oelsner, O. (1952) Die pegmatitisch-pneumatolytischen Lagerstätten des Erzgebirges mit Ausnahme der Kontaktlagerstätten. Freiberger Forsch. -H. C 4.
Pehrman, G. (1945) Die Granitpegmatite von Kimito (SW-Finland) und ihre Minerale. Acta. Acad. Aboensis, Math. Phys. 15,2.

Richmond, W. E. (1940) Crystal chemistry of the phosphates, arsenates and vanadates of the type $\mathrm{A}_{2} \mathrm{XO}_{4}(\mathrm{Z})$. Am. Mineral. 25, pp. 441-479.

SASAKI, A. (1959) Variation of unit cell parameters in wolframite. Mineral. Journ. (Japan) 2, pp. 375396.

Schröcke, H. (1960) Isomorphiebeziehungen in der Wolframitgruppe. Beitr. Mineral. Petrogr. 7, pp. 166 -206 .

WALDROP, L. (1968) Crystal structure of triplite. Naturwissenschaften 55, H. 4, p. 178.

Winchell, A. N. and Winchell, H. (1959) Elements of optical mineralogy. II. Fourth edition. John Wiley and Sons, New York.

Wolfe, C. W. and Heinrich, E. WM (1944) Triplite crystals from Colorado. Am. Mineral. 32, pp. 518 -526 .

Manuscript received, September 20, 1968. 